\title{
EVALUATION OF AN INDIRECT ELISA FOR THE DETECTION OF SALMONELLA IN CHICKEN MEAT
}

\author{
Andréa dos Santos Schneid ${ }^{1}$; Kelly Lameiro Rodrigues ${ }^{1}$; Davi Chemello²; Eduardo Cesar Tondo²; \\ Marco Antônio Zacchia Ayub² ${ }^{2}$, José Antonio Guimarães Aleixo ${ }^{1 *}$
}

${ }^{1}$ Centro de Biotecnologia, Universidade Federal de Pelotas, Pelotas, RS, Brasil; ${ }^{2}$ Instituto de Ciência e Tecnologia de Alimentos, Universidade Federal do Rio Grande do Sul, Porto Alegre, RS, Brasil

Submitted: March 15, 2005; Approved: June 14, 2006

\begin{abstract}
In this work, an indirect ELISA based on a monoclonal antibody (MAb) specific for an outer membrane protein of Salmonella enterica serovar Enteritidis was used for detection of Salmonella in 154 samples of chicken meat. Its efficiency was determined through comparison with the results obtained from the conventional method. The prevalence of samples contaminated with Salmonella was 23\% with the conventional culture method, and 26\% with the ELISA. From thirty-five samples positive for Salmonella by the conventional method, 33 were also positive by ELISA. Seven other samples were only positive in the ELISA. Comparison of the results obtained in the two methods showed an ELISA sensitivity and specificity of $94 \%$, and positive and negative predictive values of $82 \%$ and $98 \%$ respectively. The serotyping of the isolates revealed 31 Salmonella enterica serovar Enteritidis, 2 Salmonella enterica serovar Heidelberg, 1 Salmonella enterica serovar Choleraesuis and 1 Salmonella enterica sorovar 6,7:-:-.
\end{abstract}

Key words: Salmonella, monoclonal antibody, policlonal antibody, ELISA

\section{INTRODUCTION}

Salmonella bacteria are often involved in outbreaks of gastroenteritis all over the world $(21,28)$. As Salmonella is widely spread throughout the environment, contaminating water and a wide range of foods, it represents a serious problem for public health and it is therefore necessary to have fast and reliable methods of detection.

The conventional method of cultivation used in detection is reliable but slow as it includes stages of pre-enrichment, selective enrichment, cultivation in selective agars, biochemical characterisation of suspected isolates and a final serological confirmation (20). The relatively long time required to carry out analysis (4-7 days) as well as the costs incurred and the storage of foods suspected of being contaminated have stimulated the development of faster detection methods that can be useful in studies of the source of contamination and of outbreaks due to food contamination $(7,15,19)$.
Among the methods that have already been put forward are DNA hybridisation $(1,17)$, polymerase chain reaction $(3,30,35)$, tests with specific bacteriophages (4), latex agglutination tests $(9,11,32)$, immunomagnetic assays $(29,34)$ and other types of immunoenzymatic assays $(24,33,36,37)$.

The enzyme-linked immunosorbent assay (ELISA), a type of immunoenzymatic assay that uses solid phases to anchor the antibody-antigen complex, have been widely used because offer several advantages. One of these is the capacity to detect the presence of bacteria antigens without the cells having to be viable (24). Besides, many ELISA tests, mainly those that use polyclonal antibodies, show good sensitivity, but have restricted specificity for certain serovars. Others use a combination of polyclonal antibodies in order to obtain a wide spectrum of specificity. However, this method may potentialize the occurrence of unspecific reactions due to the nature and the way that these antibodies are obtained (6).

*Corresponding Author. Mailing address: Centro de Biotecnologia, Universidade Federal de Pelotas, Campus Universitário. 96030-001. Pelotas, RS, Brasil. Tel.: (+5553) 275-7350. Fax: (+5553) 275-7355. E-mail: biotjaga@ufpel.tche.br 
The use of monoclonal antibodies (MAbs) with high specificity and affinity has been a good alternative in making ELISA tests more reliable. The use of a combination of MAbs for specific Salmonella epitopes is also an important tool in order to increase the sensitivity of the ELISA (10).

This study aims to evaluate an ELISA system that uses a specific monoclonal antibody for a protein taken from the external membrane of Salmonella Enteritidis in the detection of Salmonella in naturally contaminated chicken.

\section{MATERIALS AND METHODS}

\section{Sample collection and preparation}

The flow chart of procedures (20) used during the collection and processing of samples is shown in Fig. 1. A total of 154 samples of refrigerated chicken cuts were obtained from a local shop. The samples, thighs and legs, which are normally on display in trays on refrigerated shelves, were bought and

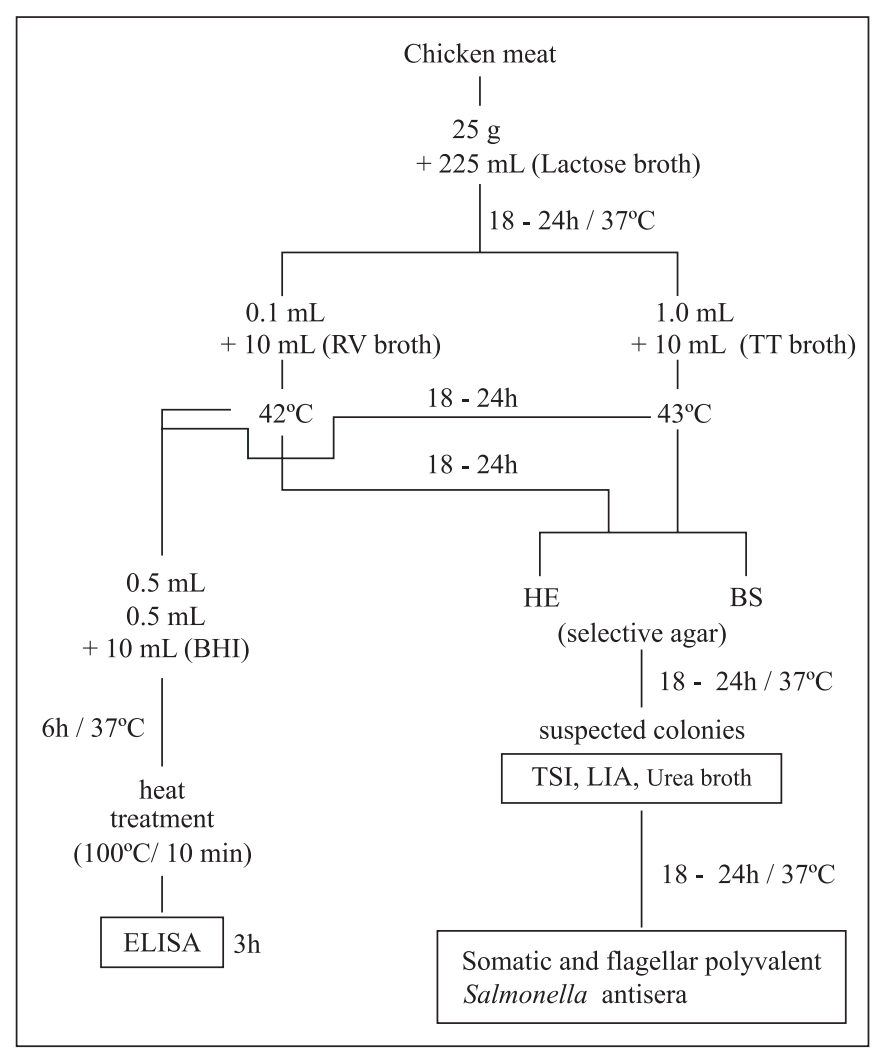

Figure 1. Flow chart used to compare the detection of Salmonella in chicken meat by conventional methodology and indirect ELISA. RV: Rappaport Vassiliadis broth; TT: tetrationate broth; HE: Hektoen agar; BS: bismuth sulphite agar; TSI: triple sugar iron agar; LIA: lysine iron agar; BHI: brain heart infusion broth. wrapped in plastic film and then placed in polystyrene with ice for transportation to the laboratory where the analyses were begun on the same day. The aseptic collection of $25 \mathrm{~g}$ samples was carried out on a laminar flow bench. The samples were then placed in sterile plastic bags containing $225 \mathrm{~mL}$ of lactose broth (LB) (Difco Laboratories, Detroit, MI), homogenised for two minutes in Stomacher ${ }^{\mathrm{TM}}$, incubated at $37^{\circ} \mathrm{C}$ for $18-24 \mathrm{~h}$ and from there on the detection stages of the two methods being compared were done.

\section{Conventional detection method}

After the incubation period, $0.1 \mathrm{~mL}$ and $1.0 \mathrm{~mL}$ of cultures in LB (Difco) were transferred, respectively, into Rappaport Vassiliadis (RV) (Difco Laboratories, Detroit, MI) and tetrationate (TT) (Difco) broths and incubated at a temperature between $42^{\circ} \mathrm{C}(\mathrm{RV})$ and $43^{\circ} \mathrm{C}(\mathrm{TT})$ for $18-24 \mathrm{~h}$. At the end of the period of selective enrichment, the broths were plated in Hektoen enteric agar (Difco) and bismuth sulphite agar (Difco) and incubated at $37^{\circ} \mathrm{C}$ for $18-24 \mathrm{~h}$ in order to isolate suspected colonies. Biochemical identification was then carried out on 3 to 5 isolated colonies by cultivation at $37^{\circ} \mathrm{C}$ for $24 \mathrm{~h}$ in triple sugar iron agar (TSI) (Difco), lisine iron agar (LIA) (Difco) and urea broth (Difco). Serological confirmation of isolates was carried out by slide agglutination using somatic polyvalent serum and in tubes using polyvalent flagellar serum (Probac, São Paulo, SP). The final serotype identification was carried out at the Adolfo Lutz Institute (São Paulo, Brazil).

\section{ELISA procedures}

After selective enrichment, portions of $0.5 \mathrm{~mL}$ of $\mathrm{RV}$ and TT were transferred into tubes containing $10 \mathrm{~mL}$ of brain heart infusion broth (BHI) in order to carry out post-enrichment for $6 \mathrm{~h}$ at $37^{\circ} \mathrm{C}$ in a water bath with agitation. The post-enriched cultures were heated $\left(100^{\circ} \mathrm{C} / 10 \mathrm{~min}\right)$ and used to sensitize four wells of polystyrene plates with $50 \mu \mathrm{L} /$ well for $1 \mathrm{~h}$ at $37^{\circ} \mathrm{C}$. The plates were washed three times with phosphate-buffered saline (0.01 M, pH 7.2) containing $0.05 \%$ Tween 20 (PBST), and two wells received $\mathrm{MAb} 424 \mathrm{H}$, that react specifically with a putative outer membrane protein from salmonellae (27), and the other two were used without MAb for control of unspecific reactions. The wells received 50 $\mu \mathrm{L}$ of the MAb diluted 1:1000 in PBST and left for $1 \mathrm{~h}$ at $37^{\circ} \mathrm{C}$. After washing the plates another three times with PBST, $50 \mu \mathrm{L} /$ well of a protein A-peroxide conjugate (Sigma, Saint Louis, MO) diluted 1:2000 in PBST was added and left for $1 \mathrm{~h}$ at $37^{\circ} \mathrm{C}$. The plates were washed a further 5 times with PBST, and $50 \mu \mathrm{L}$ well of a cromogene/substrate solution was added [40 mg of ortophenylenediamine dihydrochloride (OPD), $40 \mu \mathrm{L}$ of hydrogen peroxide- $\mathrm{H}_{2} \mathrm{O}_{2}$ and $100 \mathrm{~mL}$ of citratephosphate buffer $0.05 \mathrm{M}, \mathrm{pH} 4.5$ ] and left to react for $15 \mathrm{~min}$ in the dark at room temperature. The optical density (OD) was then read at $450 \mathrm{~nm}$ in a MR 700 microplate reader (Dynatech Laboratories, INC., Virginia). The ELISA cut off for positive 
samples corresponded to a mean OD above 0.095 , or the $96^{\text {th }}$ percentile of 20 negative samples (27). As ELISA positive control, each plate contained four wells sensitized with a thermo-extracted antigen from Salmonella Enteritidis ATCC 13076. The control antigen was obtained by heating a suspension of cells with an $\mathrm{OD}_{600}$ of 1.00 , prepared from a culture in Brain Heart Infusion broth (BHI; Difco Laboratories, Detroit, MI) at $37^{\circ} \mathrm{C}$ for $6 \mathrm{~h}$. As ELISA negative control, four wells of a mixture of antigens heat-extracted from BHI cultures of chicken samples negative for salmonellae were used. The ELISA was considered to be acceptable when the mean OD of the positive control wells was between 1.0 and 1.2 and of the negative control wells was 0.095 or less.

\section{Statistical analysis}

The data were computed using the Epi Info programme version 6.04 (13). The Yates $\mathrm{X}_{2}$ correction test with a confidence interval of $95 \%$ was used to see if there had been significant differences between the detection results of Salmonella in the samples of chicken meat using the ELISA and the conventional methodology. Sensitivity (s), specificity (sp), predictive positive value (ppv) and negative predictive value (npv) of the ELISA in the 154 samples tested were defined as: (s) probability of obtaining a positive result if the sample was truly positive, (sp) probability of obtaining a negative result if the sample was truly negative, (ppv) probability that an ELISA positive sample was truly positive, (npv) probability that an ELISA negative sample was truly negative. Accuracy, which is defined as the percentage of results that coincide in the two methods, was obtained using the rate between the number of coincidental results in the ELISA and the conventional method, and the total number of positive and negative results by the conventional method.

\section{RESULTS}

The results obtained from the analysis of the 154 chicken samples of are shown in Table 1. The prevalence of samples contaminated with Salmonella was $23 \%$ using the conventional method of cultivation and $26 \%$ using the indirect ELISA test. This difference was not statistically significant $(\mathrm{P}<0.001)$. The ELISA gave 7 false positive results and only 2 false negative results. Among the 35 samples where Salmonella was detected, 31 were contaminated with Salmonella Enteritidis, 2 with Salmonella Heildelberg, 1 with Salmonella Choleraesuis and 1 with Salmonella enterica strain 6.7:-:-.

Compared to the results obtained by the conventional method, the ELISA accuracy was $94 \%$ with sensitivity and specificity also of $94 \%$, and predictive positive and negative values of $82 \%$ and $98 \%$ respectively (Table 2).
Table 1. Detection of Salmonella in chicken meat samples by indirect ELISA and conventional methodology.

\begin{tabular}{|c|c|c|c|}
\hline Samples ${ }^{\mathrm{a}}$ & $\begin{array}{cc}\text { ELISA } & \mathrm{C} \\
\left(\mathrm{OD}_{450}\right) & \mathrm{N}\end{array}$ & $\begin{array}{l}\text { Conventional } \\
\text { Methodology }\end{array}$ & Serovar \\
\hline 1 & 0.477 & + & Salmonella Enteritidis \\
\hline 2 & 0.340 & + & Salmonella Enteritidis \\
\hline 3 & 0.347 & + & Salmonella Enteritidis \\
\hline 4 & 0.170 & + & Salmonella Enteritidis \\
\hline 5 & 0.143 & + & Salmonella Enteritidis \\
\hline 6 & 0.361 & + & Salmonella Enteritidis \\
\hline 7 & 0.298 & + & Salmonella Enteritidis \\
\hline 8 & 0.788 & + & Salmonella Enteritidis \\
\hline 9 & 0.306 & + & Salmonella Enteritidis \\
\hline 10 & 0.255 & + & Salmonella Enteritidis \\
\hline 11 & 0.246 & + & Salmonella Enteritidis \\
\hline 12 & 0.223 & + & Salmonella Enteritidis \\
\hline 13 & 0.123 & + & Salmonella Enteritidis \\
\hline 14 & 0.186 & + & Salmonella Enteritidis \\
\hline 15 & 0.183 & + & Salmonella Enteritidis \\
\hline $16^{\mathrm{b}}$ & 0.063 & + & Salmonella Enteritidis \\
\hline 17 & 0.421 & + & Salmonella Enteritidis \\
\hline 18 & 0.420 & + & Salmonella Enteritidis \\
\hline 19 & 0.275 & + & Salmonella Enteritidis \\
\hline 20 & 0.270 & + & Salmonella Enteritidis \\
\hline 21 & 0.107 & + & Salmonella Enteritidis \\
\hline 22 & 0.757 & + & Salmonella Enteritidis \\
\hline 23 & 0.286 & + & Salmonella Enteritidis \\
\hline 24 & 0.252 & + & Salmonella Enteritidis \\
\hline 25 & 0.242 & + & Salmonella Enteritidis \\
\hline 26 & 0.265 & + & Salmonella Enteritidis \\
\hline 27 & 0.342 & + & Salmonella Enteritidis \\
\hline $28^{\mathrm{b}}$ & 0.090 & + & Salmonella Enteritidis \\
\hline 29 & 0.533 & + & Salmonella Enteritidis \\
\hline 30 & 0.334 & + & Salmonella Enteritidis \\
\hline 31 & 0.576 & + & Salmonella Enteritidis \\
\hline 32 & 0.782 & + & Salmonella Choleraesuis \\
\hline 33 & 0.278 & + & Salmonella Heidelberg \\
\hline 34 & 0.311 & + & Salmonella Heidelberg \\
\hline 35 & 0.107 & + & $\begin{array}{c}\text { Salmonella enterica } \\
\text { serovar 6,7:-:- }\end{array}$ \\
\hline $36^{\mathrm{c}}$ & 0.224 & - & NI \\
\hline $37^{\mathrm{c}}$ & 0.109 & - & NI \\
\hline $38^{\mathrm{c}}$ & 0.116 & - & NI \\
\hline $39^{c}$ & 0.263 & - & NI \\
\hline $40^{c}$ & 0.104 & - & NI \\
\hline $41^{\mathrm{c}}$ & 0.107 & - & NI \\
\hline $42^{c}$ & 0.105 & - & NI \\
\hline 112 Samples & $<0.095$ & - & - \\
\hline
\end{tabular}

$\mathrm{OD}_{450}$ values over 0.095 are considered positives in ELISA; NI (no

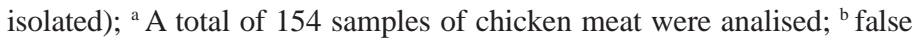
negative results in ELISA; ${ }^{\mathrm{c}}$ false positive results in ELISA. 
Table 2. Sensitivity, specificity, positive and negative predictive values of indirect ELISA for detection of Salmonella in chicken meat samples.

\begin{tabular}{lccr}
\hline \multirow{2}{*}{ Conventional } & \multicolumn{3}{c}{ Methodology } \\
\cline { 2 - 4 } ELISA & positive & negative & total \\
\hline Positive & $33^{\mathrm{a}}$ & $7^{\mathrm{b}}$ & 40 \\
Negative & $2^{\mathrm{c}}$ & $112^{\mathrm{d}}$ & 114 \\
Total & 35 & 119 & 154 \\
\hline
\end{tabular}

${ }^{a}$ positive results in ELISA; ${ }^{\text {ffalse }}$ positive results in ELISA; 'false negative results in ELISA; ${ }^{d}$ negative; results in ELISA; sensitivity (a / $\mathrm{a}+\mathrm{c})=0.94$; specificity $(\mathrm{d} / \mathrm{b}+\mathrm{d})=0.94$; positive predictive value; $(\mathrm{a} / \mathrm{a}+\mathrm{b})=0.82$; negative predictive value $(\mathrm{d} / \mathrm{c}+\mathrm{d})=0.98$.

\section{DISCUSSION}

When comparing the results obtained by the ELISA and the conventional method in the analysis of the 154 chicken samples for the detection of Salmonella, one can see that they were not statistically different. According to these results, using the conventional method the prevalence of Salmonella in chicken was $23 \%$ while using the ELISA it was $26 \%$. Both detection systems revealed a high percentage of chicken cuts contaminated with Salmonella. This finding proves how important this type of food probably is in the transmission of this bacteria to humans in our community. Animal based foods, especially chicken, have been associated with the occurence of Salmonella in humans, Salmonella Enteritidis being the most frequently isolated strain in this type of food (8). Similar results were found in this study which showed that out of a total of 35 Salmonella positive samples, 31 were of the Salmonella Enteritidis strain which in turn corresponds to $88.6 \%$ of the strains isolated.

The results reveal that the ELISA and the conventional methodology behaved in a similar fashion in terms of efficiency. The ELISA was able to detect Salmonella in 40 samples, 7 more than the conventional system, a number of false positive results reasonably low $(4.5 \%)$. This is reflected in the high values obtained for specificity (94\%) and the positive prediction value (82\%) (Table 2). Various studies comparing ELISA and conventional testing verify a tendency for ELISA tests to give false positive results $(4,7,25)$. This tendency is generally attributed to cross reactions of antibodies with antigens of others microrganisms present in the samples or to reactions with constituents in the food. However, the low number of Salmonella in the samples, cellular injury and the interference of natural flora in the multiplication of Salmonella in foods, are some factors that may contribute to difficulties or prevention of isolation thereby causing false negative results in the conventional method $(14,23)$. Also, the isolation of pathogens in some agars may be made difficult by the presence of a large number of competitive bacteria, some of which are very similar to Salmonella and which may cause error when selecting suspect colonies $(26,31)$.

Peplow et al. (25) stated that false negative results in rapid detection methods are easily proved by isolation of microorganisms using the conventional method and that, on the contrary, false positive results in rapid detection methods cannot be proved as they are, in reality, false negatives in the conventional methodology. It is therefore possible that the false positive results observed in our ELISA may be due to a detection fault in the conventional test. According to Bailey (2), the new technologies for detection of pathogens in foods are more sensitive than conventional methods besides eliminating the need for isolation to confirm the presence of pathogens.

The two false negative results given by the ELISA test (1.3\%) directly influenced sensitivity (94\%) and the predictive negative value (98\%). One explanation for the false negatives may have been the low number of Salmonella cells present in the post enrichment phase. It is possible that the natural flora present in these two samples impaired the multiplication of Salmonella cells at levels that were detectable by ELISA (16). It is also possible that the MAb $424 \mathrm{H}$ in the reaction had not retained enough enzyme to form a sufficient quantity of product to be detected by the system. An alternative to avoid this type of error is to use a combination of antibodies that are specific for Salmonella antigens in order to amplify test results by the higher number of epitopes detected (5). Another alternative would be the improvement of enrichment protocols used in the ELISA test by inhibiting microbial competition and favouring the growth of Salmonella to increase the amount of antigen available for reaction with detector antibody $(12,18,22,31)$.

In conclusion, the indirect ELISA with the MAb $424 \mathrm{H}$ used to detect the presence of Salmonella in chicken cuts allows positive results 30 hours before conventional testing. The ELISA has a sensitivity and specificity comparable to other ELISA tests already developed and commercially available. It has a good potential for use as a screening test in the quality control of the food industry.

\section{RESUMO}

\section{Avaliação de um ELISA indireto para detecção de Salmonella em carne de frango}

Neste trabalho, um ELISA indireto baseado em um anticorpo monoclonal (MAb) especifico para proteína de membrane externa de Salmonella enterica serovar Enteritidis foi usado para detecção de Salmonella em 154 amostras de carne de frango. Sua eficiência foi determinada através de comparação com os resultados obtidos pela metodologia convencional. A 
prevalência de amostras contaminadas com Salmonella foi de $23 \%$ pelo método de cultivo convencional, e $26 \%$ pelo ELISA. De 35 amostras positivas para Salmonella pela metodologia convencional, 32 também foram positivas no ELISA. Outras sete amostras foram positivas somente no ELISA. Comparando os resultados obtidos nos dois métodos, o ELISA demonstrou sensibilidade e especificidade de $94 \%$, e valor preditivo positivo e negativo de $82 \%$ e $98 \%$ respectivamente. A sorotipagem dos isolados revelou 31 Salmonella enterica serovar Enteritidis, 2 Salmonella enterica serovar Heidelberg, 1 Salmonella enterica serovar Choleraesuis e 1 Salmonella enterica sorovar 6,7:-:-.

Palavras-chave: Salmonella, anticorpo monoclonal, anticorpo policlonal, ELISA

\section{REFERENCES}

1. Bailey, J.S.; Cox, N.A.; Blankenship, L.C. A comparison of an enzyme Immunoassay, DNA hybridization, antibody immobilization, and conventional methods for recovery of naturally occurring Salmonella from processed broiler carcasses. J. Food Protect., 54, 354-356, 1991.

2. Bailey, J.S. Detection of Salmonella cells within 24 to 26 hours in poultry samples with the polymerase chain reaction BAX system. $J$. Food Protect., 61(7), 792-795, 1998.

3. Baumler, A.J.; Heffron, F.; Reissbrodt, R. Rapid detection of Salmonella enterica with primers specific for iroB. J. Clin. Microbiol., 35(5), 1224-1230, 1997.

4. Bennett, A.R.; Davids, F.G.C.; Vlahodimou, S.; Banks, J.G.; Betts, R.P. The use of bacteriophage-based systems for the separation and concentration of Salmonella. J. Appl. Bacteriol., 83, 259265, 1997.

5. Blackburn, C.W. A review. Rapid and alternative methods for the detection of salmonelas in foods. J. Appl. Bacteriol., 75, 199-214, 1993.

6. Brown, J.G.; Brooks, B.W.; Blais, B.W.; Yamazaki, H. Application of Cloth- based enzyme immunoassay for the characterization of monoclonal antibodies to Salmonella lipopolysaccharide antigens. Immunol. Investigations, 25(4), 369-381, 1996.

7. Chaicumpa, W.; Ngren-Ngarmlert, W.; Kalambaheti, T.; ChongsaNguan, Y.R.M.; Tapchaisri, P.; Desakorn, V.; Suthienkul, O. Monoclonal antibody - based Dot-Blot ELISA for the detection of Salmonella in foods. Asian Pacific J. Allergy Immunol., 13, 159166, 1995.

8. Chang, Y.H. Prevalence of Salmonella spp. in poultry broilers and shell eggs in Korea. J. Food Protect., 63(5), 655-658, 2000.

9. Cheesbrough, S.; Donnelly, C. The use of a rapid Salmonella latex serogrouping test (Spectate) to assist in the confirmation of ELISAbased rapid Salmonella screenig tests. Lett. Appl. Microbiol., 22(5), 378-380, 1996.

10. Choi, D.; Tsang, R.S.W.; NG, M.H. Sandwich capture ELISA by a murine monoclonal antibody against a genus-specific LPS epitope fo the detection of different common serotypes of salmonellas. $J$. Appl. Bacteriol., 72, 134-138, 1992.

11. D'Aoust, J.Y.; Sewell, A.M.; Greco, P. Commercial latex agglutination kits for the detection of foodborne Salmonella. J. Food Protect., 54(9), 725-730, 1991

12. D'Aoust, J.Y.; Sewell, A.N.; Daley, E. Inadequacy of small transfer volume and short (6h) selective enrichment for the detection of foodborne Salmonella. J. Food Protect., 55(5), 326-328, 1992.
13. Deam, A.G.; Deam, J.A.; Coulmobier, D.; Brendel, K.A.; Smith, D.C.; Burton, A.H.; Dicker, R.C.; Sullivan, K.; Fagan, R.F.; Arner, T.J. Epi Info version 6.0. A word processing, database, and statistics program for epidemiology on microcomputers. Centers for Disease Control and Prevention, Atlanta, GA, 1994.

14. Eckner, K.F.; Dustman, W.A.; Curiale, M.S.; Flowers, R.S.; Robison, B.J. Elevated-temperature, colorimetric, monoclonal, enzyme-linked immunosorbent assay for rapid screening of Salmonella in foods: collaborative study. J. Assoc. Off. Anal. Chem., 77(2), 374-383, 1994.

15. Fach, P.; Dilasser, F.; Grout, J.; Tache, J. Evaluation of a polimerase chain reaction-based test for detecting Salmonella spp in foods samples: Probelia Salmonella spp. J. Food Protect., 62(12), 13871393,1999

16. Feldsine, P.T.; Nelson, M.T.F.; Hustead, D.L. Policlonal enzyme immunoassay method for detection of motile and non-motile Salmonella in foods: collaborative study. J. Assoc. Off. Anal. Chem., 76(4), 694-697, 1993.

17. Fitts, R.; Diamond, M.; Hamilton, C.; Neri, M. DNA - DNA Hibridization assay for detection of Salmonella spp. in foods. Appl. Environment. Microbiol., 46, 1146-1149, 1983.

18. Flowers, R.S.; Klatt, M.J.; Robison, B.J.; Mattingly, J.A. Evaluation of abbreviated enzyme immunoassay method for detection of Salmonella in low-moisture foods. J. Assoc. Off. Anal. Chem., 71(4), 341-343, 1988.

19. Flowers, R.S.; Klatt, M.J.; Keelan, S.L.; Gehle, W.D.; Chandonnet, E. Fluorescent enzyme immunoassay for rapid screenin of Salmonella in foods: Collaborative study. J. Assoc. Off. Anal. Chem., 72(2), 318-325, 1989

20. Food and Drug Administration. Bacteriological Analitical Manual, $8^{\text {th }}$ Ed. AOAC International, Arlington, 1998.

21. Guo, X.; Chen, J.; Beuchat, L.R.; Brackett, R.E. PCR detection of Salmonella enterica sorotipo Montevideo in and on raw tomatoes using primers derived from hilA. Appl. Environ. Microbiol., 66(12), 5248-5252, 2000.

22. Kerr, S.; Ball, H.J.; Mackie, D.P.; Pollock, D.A.; Finlay, D.A. Diagnostic application of monoclonal antibodies to outer membrane protein for rapid detection of salmonella. J. Appl. Bacteriol., 72, 302-308, 1992.

23. Krusell, L.; Skovgaard, N. Evaluation of a new semi-automated screening methods for the detection of Salmonella in foods within 24 h. Int. J. Food Microbiol., 20, 123-130, 1993.

24. Ng, S.P.; Tsui, C.O.; Roberts, D.; Chau, P.Y.; Ng, M.H. Detection and serogroup differentiation of Salmonella spp. in food within 30 hours by enrichment-immunoassay with a T6 monoclonal antibody capture Enzyme-Linked Immunosorbent Assay. Appl. Environ. Microbiol., 62(7), 2294-2302, 1996.

25. Peplow, M.O.; Prisant, M.C.; Stebbins, M.E.; Jones, F.; Davies, P. Sensitive, specificity, and predictive values of three Salmonella rapid detection kits using fresh and frozen poultry environmental samples versus those of standard plating. Appl. Environ. Microbiol., 65(3), 1055-1060, 1999.

26. Rambach, A. New plate medium for facilitated differentation of Salmonella spp. from Proteus spp. and other enteric bacteria. Appl. Environ. Microbiol., 56, 301-303, 1990.

27. Schneid, A.S.; Lüdtke, C.B.; Diel, C.; Aleixo, J.A.G. Production and characterization of monoclonal antibodies for the detection of Salmonella enterica in chicken meat. Braz. J. Microbiol., 36, 163169, 2005.

28. Seo, K.H.; Hartman, N.F.; Campbell, D.P. Development of a rapid response biosensor for detection of Salmonella Typhimurium. $J$. Food Protect., 62(5), 431-437, 1999.

29. Shaw, J.S.; Blais, B.W.; Nundy, D.C. Performance of the Dynabeads anti-Salmonella systems in the detection of Salmonella species in foods, animal feeds, and environmental samples. J. Food Protect., 61(11), 1507-1510, 1998. 
30. Stone, G.G.; Oberst, R.D.; Hays, M.P.; McVey, S.; Chengappa, M.M. Combined PCR-oligonucleotide ligation assay for rapid detection of Salmonella serovars. J. Clin. Microbiol., 33(11), 2888-2893, 1995.

31. Tate, C.R.; Miller, R.G.; Mallinson, E.T. Evaluation of two isolation and two no-isolation methods for detecting naturally occurring Salmonellae from broiler flock environmental drag-swab samples. J. Food Protect., 55, 964-967, 1992.

32. Thorns, C.J.; McLaren, I.M.; Sojka, M.G. The use of latex particle agglutination to specifically detect Salmonella enteritidis. Int. J. Food Microbiol., 21, 47-53, 1994.

33. Veling, J.; Van Zijderveld, F.G.; Van Zijderveld-Van Bemmel, A.M.; Barkema, H.W.; Chukken, Y.H. Evaluation of three Newly developed Enzyme-Linked Immunosorbent Assay and two agglutination tests for detecting Salmonella enterica subsp. enterica serovar Dublin infections in Dairy cattle. J. Clin. Microbiol., 38(12), 4402-4407, 2000 .
34. Vermunt, A.E.M.; Franken, A.A.J.M.; Beumer, R.R. Isolation of salmonelas by immunomagnetic separation. J. Appl. Bacteriol., 72, $112-118,1992$

35. Way, J.S.; Josephson, K.L.; Pillai, S.D.; Abbaszadegan, M.; Gerba C.P.; Pepper, I.L. Specific detection of Salmonella spp by multiplex polymerase chain reaction. Appl. Environ. Microbiol., 59(5), 1473 1479,1993

36. Wyatt, G.M.; Langley, M.N.; Lee, H.A.; Morgan, M.R.A. Further studies on the feasibility of one-day Salmonella detection by enzymelinked immunosorbent assay. Appl. Environ. Microbiol., 59, 831390,1993

37. Wyatt, G.M.; Lee, H.A.; Dionysiou, S.; Morgan, M.R.A.; Stokely, D.J.; Al-Hajji, A.H.; Richards, J.; Sillis, A.J.; Jones, P.H. Comparison of a microtitration plate ELISA with a standard cultural procedure for the detection of Salmonella spp. in chicken. J. Food Protect. 59(3), 238-243, 1996. 